Article

\title{
Effect of Rain Peak Morphology on Runoff and Sediment Yield in Miyun Water Source Reserve in China
}

\author{
Jiajia Xu ${ }^{1, *}$, Jianjun Zhang ${ }^{1, *}$, Minyi Li ${ }^{2}$ and Fenzhong Wang ${ }^{2}$ \\ 1 School of Soil and Water Conservation, Beijing Forestry University, Beijing 100083, China \\ 2 Soil and Water Conservation Workstation in Miyun District, Beijing 101500, China; \\ minyilimysw@gmail.com (M.L.); wangfenzhongmysw@gmail.com (F.W.) \\ * Correspondence: xjj_xz@163.com (J.X.); zhangjianjun@bjfu.edu.cn (J.Z.)
}

Received: 16 September 2019; Accepted: 9 November 2019; Published: 20 November 2019

\begin{abstract}
The research on the impact of rainfall patterns on runoff and sediment yield is still insufficient, especially under natural rainfall conditions. We analyzed the influence of rain peak morphology on runoff and sediment yield based on the data of rainfall, runoff, and sediment in the bare runoff plot of Shixia, a small watershed in the Miyun district of Beijing, from 2007 to 2016. We took $0.4 \mathrm{~mm} \mathrm{~min}^{-1}$ as the standard of rain peak classification and the peak width, peak number, peak value, peak position and multi-peak continuity as the indexes of rain peak morphology. The results showed that: (1) Peak number, peak value, and peak width were significantly correlated with runoff and sediment yield, while peak position was irrelevant. The order of correlation between rain peak morphology indexes and runoff yield was peak width $(0.71)>$ peak number $(0.69)>$ peak value $(0.33)>$ peak position $(0.05)$. The order of correlation between rain peak morphological indexes and sediment yield was peak width $(0.62)>$ peak value $(0.36)>$ peak number $(0.36)>$ peak position $(-0.09)$. The multi-peak continuity was not correlated with runoff $(0.12)$ and sediment yield $(0.45)$. (2) When the number of rain peaks was greater than one in a single rainfall, the amount of runoff and sediment production increased significantly. (3) For multi-peak rainfall, $90 \mathrm{~min}$ was the boundary point of the rain peak interval, and the sediment yield formed by rainfall with a rain peak continuity $>1 / 90 \mathrm{~min}^{-1}$ was significantly larger than the rainfall of $\leq 1 / 90 \mathrm{~min}^{-1}$. (4) Covariance analysis showed that the runoff caused by rainfall with a peak at the middle positions was obviously more than rainfall with a peak at the front position. However, the peak position had no significant effect on the sediment yield. (5) The peak rainfall amount of a rainfall (TPR) was a comprehensive index reflecting peak number, peak value and peak width, and the correlation between it and the sediment yield and runoff reached 0.60 and 0.71 , respectively. Statistical rainfall characteristic indexes included rainfall amount, average rainfall intensity, rainfall duration, $I_{5}$ (maximum 5-min rainfall intensity), $I_{10}, I_{15}, I_{20}, I_{30}$, and $I_{60}$, among which $I_{60}$ had the strongest correlation with runoff and sediment yield $(0.69,0.60)$, which were much larger than other rainfall indexes $(0.08 \sim 0.47,0.14 \sim 0.48)$ except rainfall amount $(0.75$, 0.37). By establishing a regression equation, it was found that both TPR and $I_{60}$ had good explanatory power for runoff and weak explanatory power for sediment yield.
\end{abstract}

Keywords: rainfall peak; morphological characteristics; runoff; sediment yield

\section{Introduction}

Researchers usually use statistical rainfall indicators such as average rainfall intensity and rainfall amount to analyze the relationship between rainfall and soil erosion. Rainfall intensity was found to be the most important factor, the increase of which lead to an increase of runoff and erosion [1-3]. However, 
many scholars thought that the explanatory power of the above indicators is limited. For example, in the Loess Plateau and Northeast China, the correlation between rainfall amount and soil erosion is very low [4,5], and the maximum rainfall during the period, such as $I_{30}$ (maximum 30-min rainfall intensity), was chosen as the rainfall indicator $[6,7]$.

In previous experimental studies using artificial rainfall, researchers mainly focused on the effects of even rainfall intensity on surface infiltration, runoff, and soil loss [8-10]. However, studies have shown that the internal structure of rainfall processes, i.e., rainfall patterns, had an important influence on infiltration, runoff, and erosion processes [11-13]. Dunkerley [14] scoured dry soil with crusts and without vegetation using instantaneously varied rainfall intensity generated by artificial rainfall experiments. The results showed that the runoff coefficient and flood peak caused by the rainfall process with constant instantaneous rainfall intensity were significantly increased by $570 \%$ compared with the rainfall process with even rainfall intensity. In artificial rainfall experiments, if the rainfall pattern cannot be designed to match the rainfall characteristics of the local natural rainfall process, the estimation of soil erosion can be erroneous.

Since the soil erosion process is affected by multi-factor coupling, erosion intensity prediction is a current problem for academics, especially the uncertainty of time scale predictions of individual rainfall. Regardless of which statistical models or physical models are used, the relative errors of related studies are mostly between $20 \%$ and $30 \%$, rather than within 10\% [15]. Hudson's study [16] in south-central Africa found that a total kinetic energy of individual rainfall stronger than $25 \mathrm{~mm} / \mathrm{h}$ could be regarded as an index of erosivity, which is called the Kinetic Energy (KE) $>25$ method. Huff [17] equally divided the rainfall duration into four periods according to which quarter of the rainfall duration the peak rainfall intensity occurred. All of these studies contributed to the improvement of soil erosion model accuracy.

This paper creatively proposes a morphological index of rainfall peaks to characterize rainfall and to analyze its effects on runoff and sediment yield, which includes peak number, peak value, peak position, peak width, and multi-peak continuity. It is rare to analyze the effect of rainfall on runoff and sediment yield from the point of view of rain peak morphology. Only some studies on peak position are available, as mentioned above. Based on 46 rainfall data points we aimed to: (1) quantitatively analyze the effect of the morphological characteristics of rainfall peak on runoff and sediment yield, (2) compare the advantages and disadvantages of the morphological indexes of rainfall peak with the traditional statistical rainfall indexes, and (3) propose an applied model of runoff and sediment yield based on rain peak morphological indexes.

\section{Materials and Methods}

\subsection{Study Area}

The Shixia watershed is located in the northeast of the upper reaches of Miyun reservoir in Beijing, within the primary protection zone of the Miyun reservoir, between $117^{\circ} 01^{\prime}-117^{\circ} 07^{\prime} \mathrm{E}$ and $47^{\circ} 32^{\prime}-47^{\circ} 38^{\prime} \mathrm{N}$, with a total watershed area of $33 \mathrm{~km}^{2}$, as shown in Figure 1 . The small Shixia watershed is also located in the Yanshan mountain range, in the transition zone from the piedmont alluvial plain to the mountainous region. It is an earth-rock shallow hilly area with high terrain in the north and low terrain in the south, whose altitude is $150-390 \mathrm{~m}$. The gully density is $0.2 \mathrm{~km} \mathrm{~km}^{-2}$, and the slopes are gentle with a slope grade larger than $20^{\circ}$ only accounting for $16.2 \%$ of the watershed area. The lithology is dominated by gneiss, among which are scattered granite and limestone. The soil type is brown soil developed on alluvial and diluvial parent materials with light soil texture, deep soil layer, compact soil mass, and shallow tillage layer. The basin has a warm temperate monsoon climate. It is dry and cold in winter with an average temperature in January of $-6.6^{\circ} \mathrm{C}$ and is hot in summer with an average temperature in July of $25.3^{\circ} \mathrm{C}$. The annual evaporation of the whole basin is $1840 \mathrm{~mm}$, and the annual average rainfall is $661.8 \mathrm{~mm}$. Eighty percent of the precipitation occurs from June to September. The vegetation in the northern part of the basin is dominated by weeds and 
shrubs. The vegetation in the hilly area is mostly artificial Robinia pseudoacacia, Pinus tabulaeformis, and economic forest. Human activities have been frequent for a long time, and natural vegetation types, having been destroyed, are hard to see.

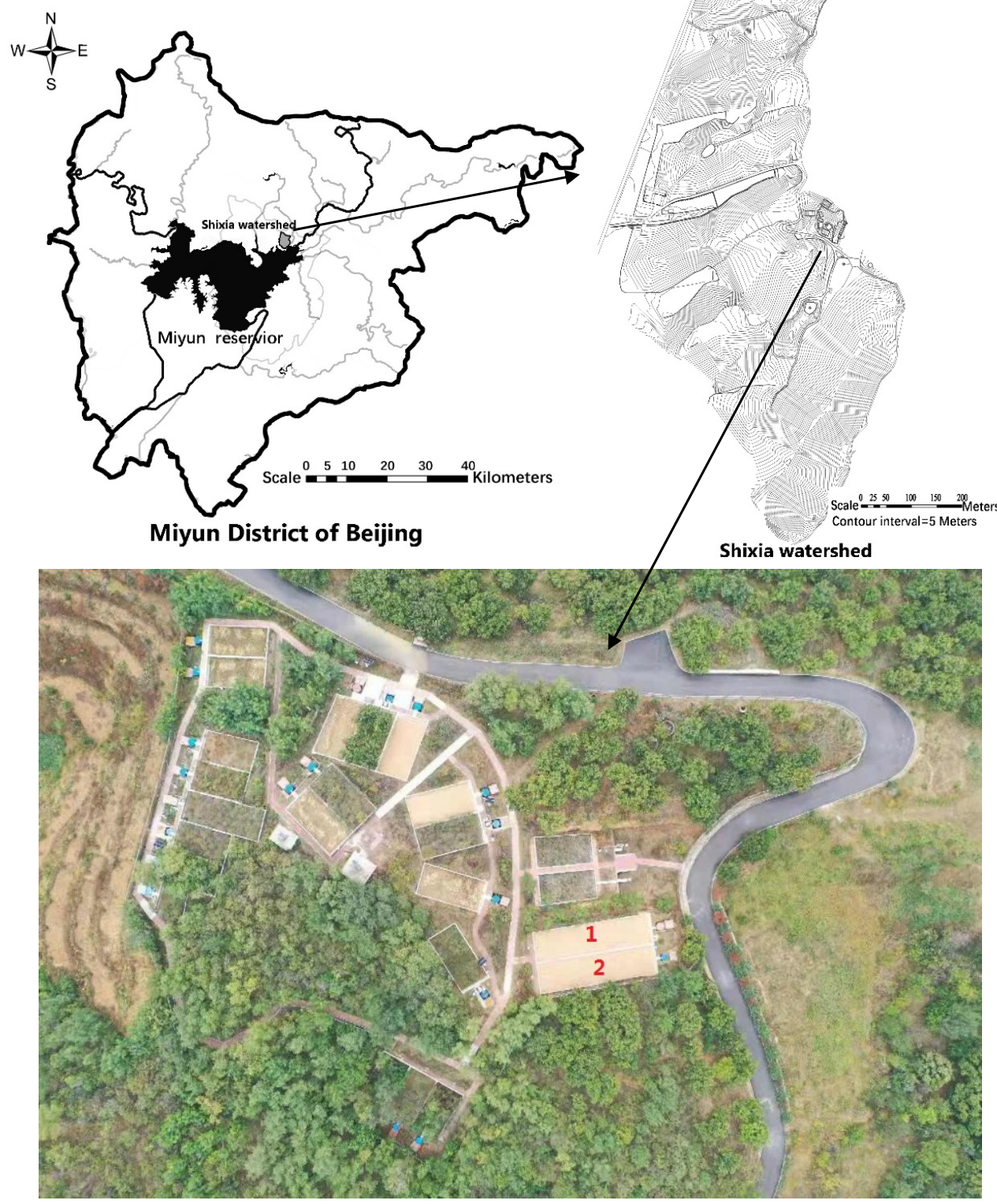

Figure 1. Location of Shixia watershed and runoff plot.

\subsection{Sampling Site and Experimental Design}

The data in this study were collected from two bare land runoff plots, which are located in the central demonstration area of the Shixia watershed. The two plots both are $20 \mathrm{~m}$ long and $5 \mathrm{~m}$ wide, with a slope of $14.4^{\circ}$, a slope direction of $\mathrm{N} 270^{\circ}$ and $20 \mathrm{~cm}$ of soil. Figure 1 is a schematic diagram of the location of the Shixia watershed and runoff plot. 


\subsection{Rainfall Data Acquisition and Rainfall Characteristic Index Selection}

Rainfall was measured by a self-recording rain gauge and standard rain barrel. According to the rainfall records, the rainfall amount, rainfall duration, rainfall intensity, $I_{5}$ (maximum 5-min rainfall intensity), $I_{10}, I_{15}, I_{20}, I_{30}$, and $I_{60}$ were calculated (see Table A1 for data).

In the selection of rainfall characteristic indexes, the morphology of the whole rainfall process needed to be considered. Therefore, on the basis of sorting and analyzing 46 rainfall data points, we put forward rain peak-related indexes to reflect the rainfall characteristics. The minimum peak of rainfall intensity that could cause bare land erosion in this research area was $0.4 \mathrm{~mm} \mathrm{~min}^{-1}$, so rainfall with a rainfall intensity above $0.4 \mathrm{~mm} \mathrm{~min}^{-1}$ was defined as the rain peak. The definition of specific rain peak morphological indexes were as follows:

Peak number: the number of peaks during a single rainfall.

Peak position: according to the time of the occurrence of the peak during a rainfall, it could be divided into the front position, middle position, and rear position. The rainfall peak is in the front position in $0-30 \%$, in the middle position in $30-60 \%$ and in the back position in $60-100 \%$ of the rainfall duration. The peak position of a multi-peak rainfall, where the number of rainfall peaks was more than one, was determined by the occurrence time of $40 \%$ of the rainfall concentration according to the dividing method of Wang [18]. According to this, rainfall could be divided into front-position rainfall, middle-position rainfall, rear-position rainfall, and uniform rainfall.

Peak value: the highest rainfall intensity. The peak during a single rainfall with the highest value was the highest peak.

Peak width: referred to the duration when the rainfall intensity reached above $0.4 \mathrm{~mm} \mathrm{~min}^{-1}$.

Peak continuity: the reciprocal of the average interval time between adjacent rainfall peaks. The interval between two adjacent peaks refers to the time from the end of the previous peak to the head of the following peak. This paper attempted to analyze the influence of different multi-peak continuities on runoff and sediment yield, besides the correlation analysis of multi-peak continuity and runoff and sediment yield, the difference of runoff and sediment yield caused by multi-peak continuity within and outside $1 / 60 \mathrm{~min}^{-1}$ and $1 / 90 \mathrm{~min}^{-1}$ were analyzed by variance analysis by taking the multi-peak continuity of $1 / 60 \mathrm{~min}^{-1}$ and $1 / 90 \mathrm{~min}^{-1}$ as dividing nodes.

Peak rainfall: The total peak rainfall amount of one rainfall was referred to as TPR for short, and the rainfall amount of the highest peak of a single rainfall was referred to as HPR for short.

The data were shown in Table A2.

\subsection{Runoff and Erosion Measurements}

Runoff and sediment were measured in runoff plots. The volume method was used to measure runoff after each rainfall event. When the amount of slurry was small, $1000 \mathrm{~mL}$ of slurry sample was taken after full mixing. When there was more mud, stratified sampling was conducted, and $500 \mathrm{~mL}$ was taken in each layer. Runoff and sediment were calculated by dividing the total amount of the two plots by the total area of the two plots (see Table A3 for data).

\subsection{Coefficient of Variation}

The coefficient of variation $\left(C_{v}\right)$ was used to reflect the inter-annual changes in precipitation, runoff, and sediment. It is calculated using the following equation:

$$
C_{v}=S_{d} / M
$$

where $S_{d}$ is the standard deviation, $M$ is the average. The greater the $C_{v}$ value of precipitation or runoff, which means the greater the variation range of precipitation or runoff, the greater the possibility of flood or drought. The larger the $C_{v}$ value of sediment yield, which means the greater the variation range of sediment yield, the more common the disasters such as soil erosion are. 


\subsection{Construction and Test of the Regression Equation}

On the basis of Pearson correlation analysis, a regression equation was established by selecting the rainfall characteristic indexes that were most closely related to soil erosion, and the application accuracy of the regression equation was determined by cross-examination. The accuracy evaluation indexes include the mean relative error $(M R E)$, coefficients of determination $\left(R^{2}\right)$ and Nash-Suttclife efficiency coefficient $\left(E_{n s}\right)$.

$$
\begin{gathered}
\text { MRE }=\frac{1}{n} \sum_{i=1}^{n}\left|\frac{O_{i}-Y_{i}}{O_{i}}\right|, \\
R^{2}=\frac{\left(\sum_{i=1}^{n}\left(O_{i}-\bar{O}\right)\left(Y_{i}-\bar{Y}\right)\right)^{2}}{\sum_{i=1}^{n}\left(O_{i}-\bar{O}\right)^{2} \sum_{i=1}^{n}\left(Y_{i}-\bar{Y}\right)^{2}} \\
E_{n s}=1-\frac{\sum_{i=1}^{n}\left(Y_{i}-O_{i}\right)^{2}}{\sum_{i=1}^{n}\left(Y_{i}-\bar{O}\right)^{2}},
\end{gathered}
$$

$Y_{i}$ is the calculated value, $O_{i}$ is the measured value, $\bar{O}$ is the average value of the measured value, $\bar{Y}$ is the average value of the calculated value, and $n$ is the number of data points.

\section{Results}

\subsection{Rainfall Characteristics Analysis}

During the 10 years from 2007 to 2016, there were 101 erosive rainfalls in the small Shixia watershed. In order to analyze the impact of rainfall on runoff and sediment yield, we had to eliminate the previous rainfall events as much as possible, so 45 precipitation events without rainfall in the previous two days were selected. The total rainfall of these 45 rainfall events was $1494.4 \mathrm{~mm}$ with an average rainfall of $33.2 \mathrm{~mm}$, a maximum rainfall of $114.3 \mathrm{~mm}$ and a minimum rainfall of $9.8 \mathrm{~mm}$. The average rainfall duration was $391.0 \mathrm{~min}$, with a maximum rainfall duration of $1225.0 \mathrm{~min}$, and a minimum rainfall duration of $20.0 \mathrm{~min}$.

A total of 81 rain peaks appeared in 45 rainfall events (Table 1), and the maximum number of rain peaks that appeared in one rainfall event was five. There were 26 single-peak rainfall events, accounting for $41 \%$ of the total rainfall, and 19 multi-peak rainfall events, accounting for $59 \%$ of the total rainfall. In the multi-peak rainfall events, there were three rainfalls with a peak continuity of less than $1 / 90 \mathrm{~min}^{-1}$ and 16 rainfalls with a peak continuity more than $1 / 90 \mathrm{~min}^{-1}$. Among the 81 rainfall peaks, the numbers that had a front position, middle position and rear position were 29,30 , and 22 , respectively. Among the 45 rainfall events, the numbers that had a front position, middle position and rear position were 24,13 , and 8 , respectively. It could be seen that the front-position rainfall in the research area was predominant and accounted for $53 \%$ of the total erosive storms.

Table 1. Statistics of the rainfall peak characteristics.

\begin{tabular}{ccccccc}
\hline $\begin{array}{c}\text { Rainfall } \\
\text { Characteristics }\end{array}$ & Category & $\begin{array}{c}\text { Number of } \\
\text { Rainfall }\end{array}$ & $\begin{array}{c}\text { Number of } \\
\text { Peaks }\end{array}$ & $\begin{array}{c}\text { Average } \\
\text { Rainfall }\end{array}$ & $\begin{array}{c}\text { Average Rainfall } \\
\text { Duration }\end{array}$ & $\begin{array}{c}\text { Average Rainfall } \\
\text { Intensity }\end{array}$ \\
\hline \multirow{2}{*}{ Peak Number } & single-peak & 26 & - & 23.67 & 297.23 & 12.75 \\
& multi-peak & 19 & - & 46.26 & 519.21 & 7.77 \\
\hline \multirow{2}{*}{ Peak position } & front & 24 & 29 & 22.75 & 235.25 & 12.66 \\
& middle & 13 & 30 & 48.81 & 532.85 & 7.25 \\
\hline Rain peak & rare & 8 & 22 & 39.25 & 627.50 & 10.12 \\
continuity & $>1 / 90$ min $^{-1}$ & 3 & - & 30.17 & 998.33 & 4.72 \\
\hline
\end{tabular}


Figure 2 shows the frequency distribution of the rainfall peak value and peak width. The frequency distribution of the rainfall peak value in this region was in accordance with the Voiht peak shape function, and the peak value of rainfall was from 0.4 to $3.2 \mathrm{~mm} \mathrm{~min}^{-1}$, of which $0.8-1.2 \mathrm{~mm} \mathrm{~min}{ }^{-1}$ was most common, accounting for $33 \%$. The frequency distribution of the rainfall peak width was in accordance with the extreme distribution. The peak width of rainfall was generally less than $60 \mathrm{~min}$, of which 10-20 min was most common, accounting for $38 \%$. The frequency distribution of a single rain peak width conformed to the extreme peak function. The duration of a single rain peak was generally below $40 \mathrm{~min}$, and the majority were about $5-10 \mathrm{~min}$, which accounted for $29 \%$, followed by $10-15 \mathrm{~min}$, which accounted for $28 \%$.

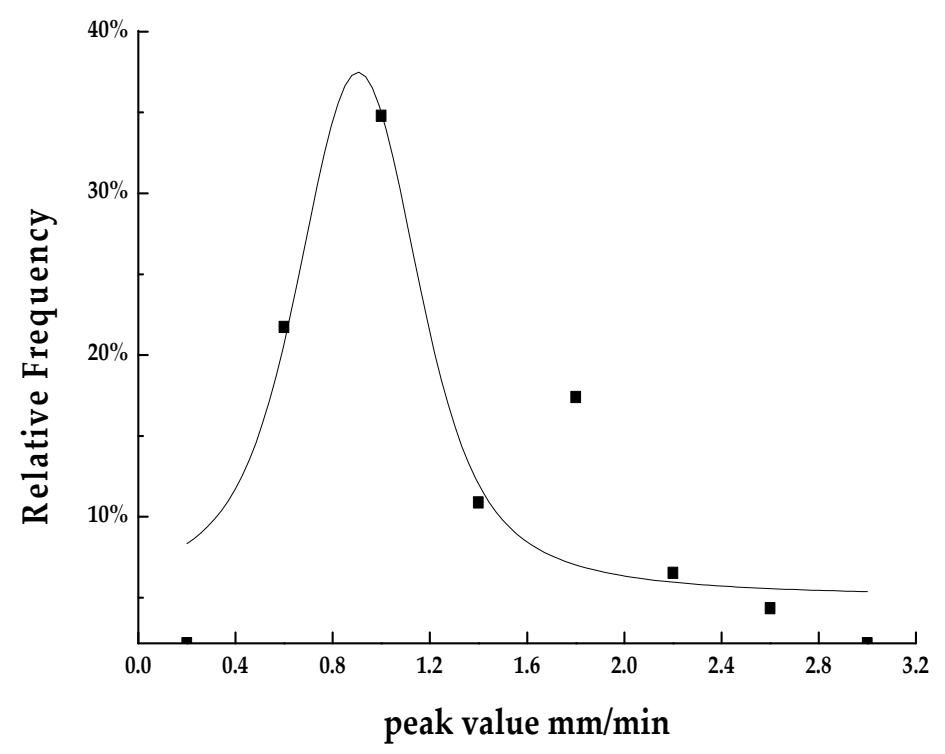

(a)

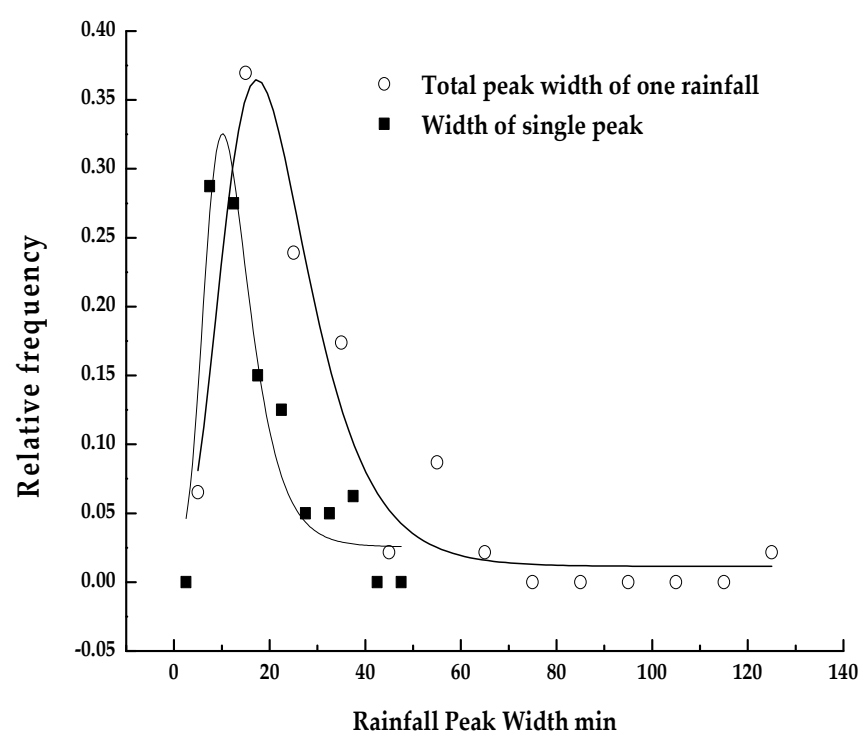

(b)

Figure 2. Frequency distribution of rainfall peak and peak width. (a) Frequency distribution of rainfall peak value, (b) frequency distribution of peak width. 


\subsection{Effect of Rain Peak Morphology on Runoff and Sediment Yield}

\subsubsection{Effect of Peak Number, Peak Position and Peak Continuity on Runoff and Sediment Yield}

Taking the peak number of 46 rainfalls as independent variables, and runoff and sediment yield as dependent variables, one-way analysis of variance was carried out. The results are shown in Table 2. Table 2 shows that there were significant differences in runoff and sediment yield between single-peak and multi-peak rainfalls $(P<0.05)$. The average runoff of multi-peak rainfalls was 2.83 times that of single-peak rainfalls, and the average sediment yield of multi-peak rainfalls was 1.49 times that of single-peak. It could be seen that if the rainfall peaks reached two or more, the amount of soil and water erosion would increase significantly.

There was no obvious difference in runoff and sediment yield caused by rainfalls with peak continuity divided by $1 / 60 \mathrm{~min}^{-1}$, and there was no significant difference in runoff caused by rainfalls with peak continuity divided by $1 / 90 \mathrm{~min}^{-1}$. When the effect of multi-peak continuity on sediment yield was analyzed, the difference was found to be significant $(P<0.05)$. However, after excluding the effect of rainfall as a covariate, it was found that multi-peak continuity had a significant effect on sediment yield at the level of $0.1(P=0.075)$. With the increase in multi-peak continuity, the sediment yield showed an increasing trend. The average sediment yield of multi-peak rainfalls with continuity $>1 / 90 \mathrm{~min}^{-1}$ was 2.95 times that of rainfalls with continuity $\leq 1 / 90 \mathrm{~min}^{-1}$.

The peak position of 46 rainfalls were taken as independent variables, runoff and sediment yield were taken as dependent variables, rainfall amount were taken as covariates to exclude their influence, and covariance analysis was carried out. The results showed that there was no significant difference in soil erosion among front-position, middle-position, and rear-position rainfalls. However, the runoff formed by the front-position rainfall was significantly different from the runoff formed by the middle-position rainfall $(P<0.05)$, while the runoff and sediment yield formed by the rear-position rainfall was no significantly different from the runoff formed by front-position and middle-position rainfalls. The average runoff of the middle-position rainfall was 3.06 times that of the front-position rainfall, which indicated that the later the rain peak appeared, the more runoff that would be generated.

Table 2. Runoff and sediment yield under different peak numbers, peak positions, and peak continuities.

\begin{tabular}{|c|c|c|c|c|c|c|c|c|c|}
\hline \multirow{2}{*}{$\begin{array}{c}\text { Rainfall } \\
\text { Characteristics }\end{array}$} & \multirow{2}{*}{ Category } & \multicolumn{3}{|c|}{ Average Sediment Yield $\left(\mathrm{t} \mathrm{km}^{-2}\right)$} & \multirow{2}{*}{$\begin{array}{c}\text { Total } \\
\text { Sediment } \\
\text { Yield }\left(\mathrm{t} \mathrm{km}^{-2}\right)\end{array}$} & \multicolumn{3}{|c|}{ Average Runoff Yield (mm) } & \multirow{2}{*}{$\begin{array}{c}\text { Total } \\
\text { Runoff } \\
\text { Yield (mm) }\end{array}$} \\
\hline & & Value & $\begin{array}{c}\text { Standard } \\
\text { Deviation }\end{array}$ & Figure & & Value & $\begin{array}{c}\text { Standard } \\
\text { Deviation }\end{array}$ & Figure & \\
\hline \multirow{2}{*}{ Peak number } & single & 625.17 & 522.19 & $\mathrm{a}$ & $16,254.42$ & 6.45 & 5.21 & a & 167.93 \\
\hline & multi & 969.87 & 552.58 & $\mathrm{~b}$ & $18,427.53$ & 20.05 & 11.62 & $\mathrm{~b}$ & 380.95 \\
\hline \multirow{2}{*}{$\begin{array}{l}\text { Rain peak } \\
\text { continuity }\end{array}$} & $\leq 1 / 90 \mathrm{~min}^{-1}$ & 363.01 & 229.42 & $\mathrm{a}$ & 1089.05 & 10.81 & 8.95 & a & 32.42 \\
\hline & $>1 / 90 \mathrm{~min}^{-1}$ & 1071.84 & 527.70 & $\mathrm{~b}$ & $17,149.48$ & 21.83 & 15.43 & a & 349.28 \\
\hline \multirow{3}{*}{ Peak position } & front & 625.31 & 526.98 & a & $16,350.00$ & 6.55 & 5.28 & a & 157.43 \\
\hline & middle & 1055.15 & 606.93 & a & $13,716.98$ & 20.05 & 11.58 & $\mathrm{~b}$ & 260.63 \\
\hline & rear & 770.71 & 556.32 & a & 5708.69 & 16.39 & 13.02 & $a b$ & 131.10 \\
\hline
\end{tabular}

Note: Averages followed by the same letter in the same column are not significantly different, according to the Fisher LSD test at $P \leq 0.05, P$ means significance test probability.

\subsubsection{Effect of Peak Value and Peak Width on Runoff and Sediment Yield}

Figure 3 shows the variation in runoff and sediment yield with the peak value. With an increase in the peak value, the average runoff and sediment yield increased gradually. The average runoff and sediment yield with a peak value $>2 \mathrm{~mm} \mathrm{~min}^{-1}$ were 2.58 times and 2.09 times higher than those with a peak value in the range of $0.4-0.8 \mathrm{~mm} \mathrm{~min}^{-1}$, respectively. Rainfall with a peak value from 0.8 to $1.2 \mathrm{~mm} \mathrm{~min}^{-1}$ produced the largest amount of runoff, which was up to $146.50 \mathrm{~mm}$, accounting for $27 \%$ of runoff generated by all rainfalls. Although the average runoff of one rainfall within this peak range was the smallest, the number of rainfalls was the highest (15, see Figure 2), thus contributing greatly to the total runoff. Rainfalls with a peak value of $0.8-1.2 \mathrm{~mm} \mathrm{~min}^{-1}$ also produced the largest amount of sediment, which was up to $8825.33 \mathrm{t} \mathrm{km}^{-2}$, accounting for $25 \%$ of the sediment generated by all rainfalls because of the high number of rainfalls. 


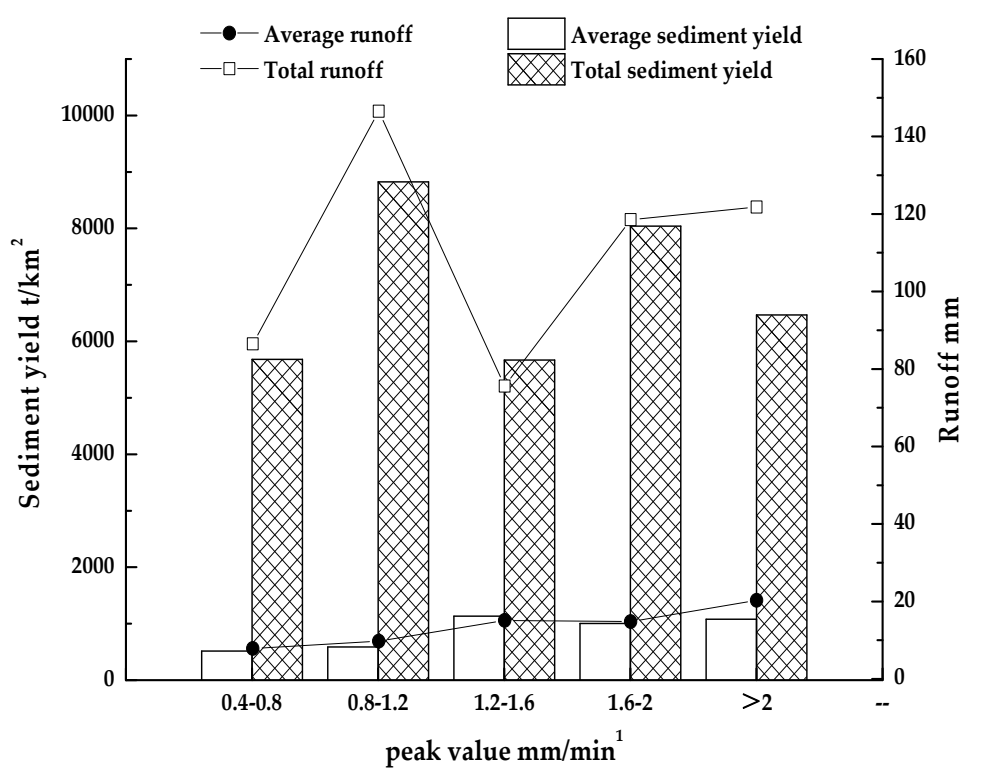

Figure 3. Runoff and sediment yield characteristics of different peak values of the rainfalls.

Figure 4 shows the runoff and sediment yield characteristics of rainfalls with different peak widths. With an increase in the peak width of the rainfall, the average runoff and the average sediment yield showed an increasing trend. Compared with rainfalls with a peak width $<10 \mathrm{~min}$, the runoff yield and sediment yield formed by rainfalls with a peak width $>60$ min increased by 7.16 times and 8.05 times, respectively. Rainfall with a peak width of 20-30 min produced the largest amount of runoff, which was up to $149.79 \mathrm{~mm}$, accounting for $27 \%$ of runoff generated by all rainfalls. Rainfall with a peak width of 20-30 min not only produced high average runoff $(13.62 \mathrm{~mm})$ but also had high rainfall times (11, see Figure 2), thus contributing greatly to the total runoff. Rainfalls with a peak width of $10-20 \mathrm{~min}$ produced the largest amount of sediment, which was up to $9099.07 \mathrm{t} \mathrm{km}^{-2}$, accounting for $26 \%$ of the sediment generated by all rainfalls. This was mainly due to the largest number of rainfalls within $10-20 \mathrm{~min}$ (17, see Figure 2), accounting for $38 \%$ of the total rainfalls.

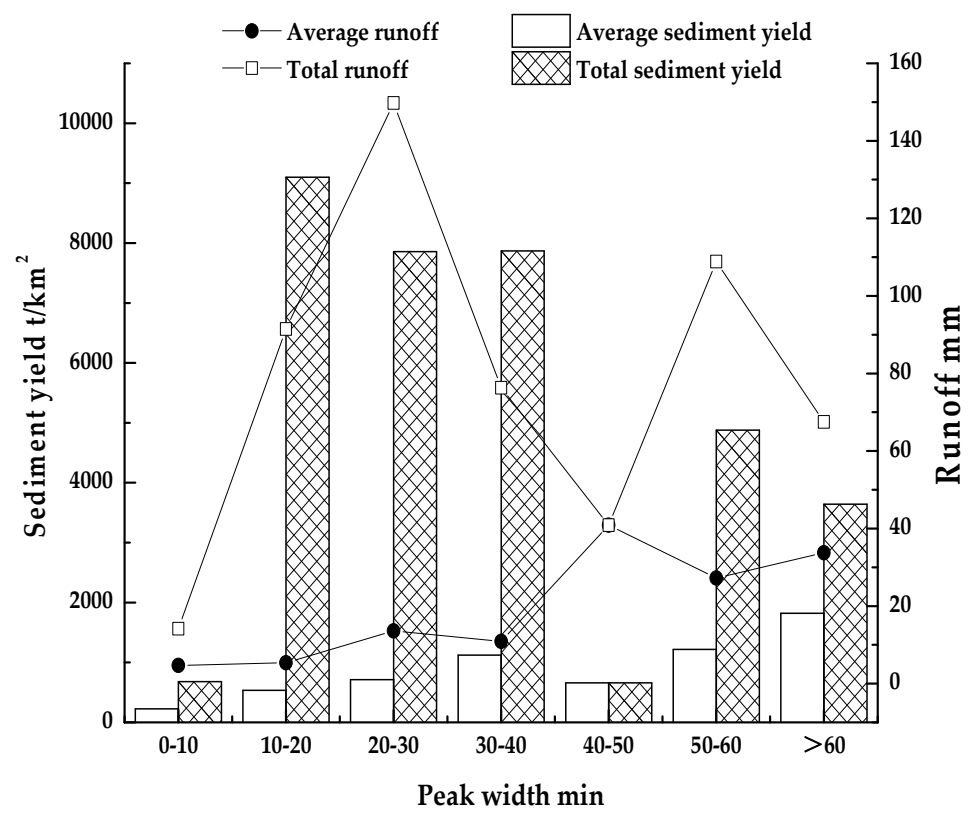

Figure 4. Runoff and sediment yield characteristics of rainfalls with different peak widths. 


\subsubsection{Comprehensive Effect of Rainfall Peak Morphology on Runoff and Sediment Yield}

The results of the correlation analysis between runoff, sediment yield, and rainfall peak morphological indexes are shown in Table 3. The order of influence of rainfall peak morphology indexes on runoff was peak width $(0.71)>$ peak number $(0.69)>$ peak value $(0.33)>$ peak position (0.05). The influence on sediment was peak width $(0.62)>$ peak value $(0.36)>$ peak number $(0.36)>$ peak position (-0.09). The correlation of multi-peak continuity to runoff and sediment yield could not be compared with other indexes because of the small sample size. Table 4 shows that multi-peak continuity is not significantly correlated with runoff $(0.12)$ and sediment yield $(0.45)$. It is worth noting that the correlation coefficients of the peak width of one rainfall with the runoff and sediment yield were 0.71 and 0.62 , respectively, which were much larger than that of the width of the highest peak with the runoff and sediment yield (0.36 and 0.49). Based on the statistical analysis of the influence of and the highest peak rainfall (HPR) on runoff and sediment yield, it was concluded that the influence of TPR on runoff and sediment yield was greater than that of $H P R$, which indicates that the explanatory power of runoff and sediment yield was weak when only the highest peak rainfall was considered.

Table 3. Correlation table between morphological indexes of rain peak with runoff and sediment yield.

\begin{tabular}{ccccccccc}
\hline Variable & $\begin{array}{c}\text { Peak } \\
\text { Number }\end{array}$ & $\begin{array}{c}\text { Peak } \\
\text { Continuity }\end{array}$ & $\begin{array}{c}\text { Peak } \\
\text { Position }\end{array}$ & $\begin{array}{c}\text { Peak } \\
\text { Value }\end{array}$ & $\begin{array}{c}\text { Peak Width of a } \\
\text { Rainfall }\end{array}$ & $\begin{array}{c}\text { Highest } \\
\text { Peak Width }\end{array}$ & TPR & HPR \\
\hline Runoff & $0.69^{* *}$ & 0.12 & 0.05 & $0.33^{*}$ & $0.71^{* *}$ & $0.36^{*}$ & $0.71^{* *}$ & $0.37^{*}$ \\
Sediment & $0.36^{*}$ & 0.45 & -0.09 & $0.36^{*}$ & $0.62^{* *}$ & $0.49^{* *}$ & $0.60^{* *}$ & $0.38^{* *}$ \\
\hline \multicolumn{7}{c}{ Note: * and ${ }^{* *}$ mean significant differences at 0.05 and 0.01 level, respectively. }
\end{tabular}

Table 4. Correlation of statistical characteristic indicators of rainfall with sediment yield and runoff.

\begin{tabular}{cccccccccc}
\hline Variable & $\begin{array}{c}\text { Rainfall } \\
\text { Amount }\end{array}$ & $\begin{array}{c}\text { Average Rainfall } \\
\text { Intensity }\end{array}$ & $\begin{array}{c}\text { Rainfall } \\
\text { Duration }\end{array}$ & $\boldsymbol{I}_{\mathbf{5}}$ & $\boldsymbol{I}_{\mathbf{1 0}}$ & $\boldsymbol{I}_{\mathbf{1 5}}$ & $\boldsymbol{I}_{\mathbf{2 0}}$ & $\boldsymbol{I}_{\mathbf{3 0}}$ & $\boldsymbol{I}_{\mathbf{6 0}}$ \\
\hline Runoff & $0.75^{* *}$ & -0.08 & $0.30^{*}$ & $0.33^{*}$ & $0.31^{*}$ & $0.40^{* *}$ & $0.47^{* *}$ & $0.44^{* *}$ & $0.69^{* *}$ \\
Sediment & $0.37^{*}$ & 0.14 & -0.15 & $0.36^{*}$ & $0.28^{* *}$ & $0.38^{* *}$ & $0.44^{* *}$ & $0.48^{* *}$ & $0.60^{* *}$ \\
\hline
\end{tabular}

Note: ${ }^{*}$ and ${ }^{* *}$ mean significant differences at the 0.05 and 0.01 level, respectively.

$T P R$ was closely related to runoff and sediment yield, which might be due to the comprehensive consideration of the impact of multi-peaks, peak value and peak width, thus greatly enhancing the interpretation of runoff and sediment yield. However, TPR still failed to consider the peak continuity and peak position, which would weaken the explanatory power of runoff and sediment yield to a certain extent. Figure 5 shows the variation of runoff and sediment yield with the TPR of 45 rainfalls. From Figure 5, it can be seen that the trend of runoff and sediment yield was obviously consistent with TPR.

In this study, the annual variability coefficients of the runoff and sediment yield were calculated and their variations with TPR were plotted (Figure 6). The $C_{v}$ of the runoff was from 0.49 to 1.24 , and the $C_{v}$ of the sediment yield was from 0.37 to 1.20 . The $C_{v}$ of the sediment yield was smaller than that of the runoff. The $C_{v}$ value of the runoff and sediment was larger than that of TPR (0.41-0.97). With an increase in TPR, the $C_{v}$ of the runoff and sediment yield also showed an increasing trend, which indicated that the runoff and sediment yield were more sensitive to heavy rainfall. That is, runoff and sediment yield caused by rainfall with high intensity and huge amount fluctuated more, which was more disadvantageous to watershed management, flood control, and disaster prevention management. 


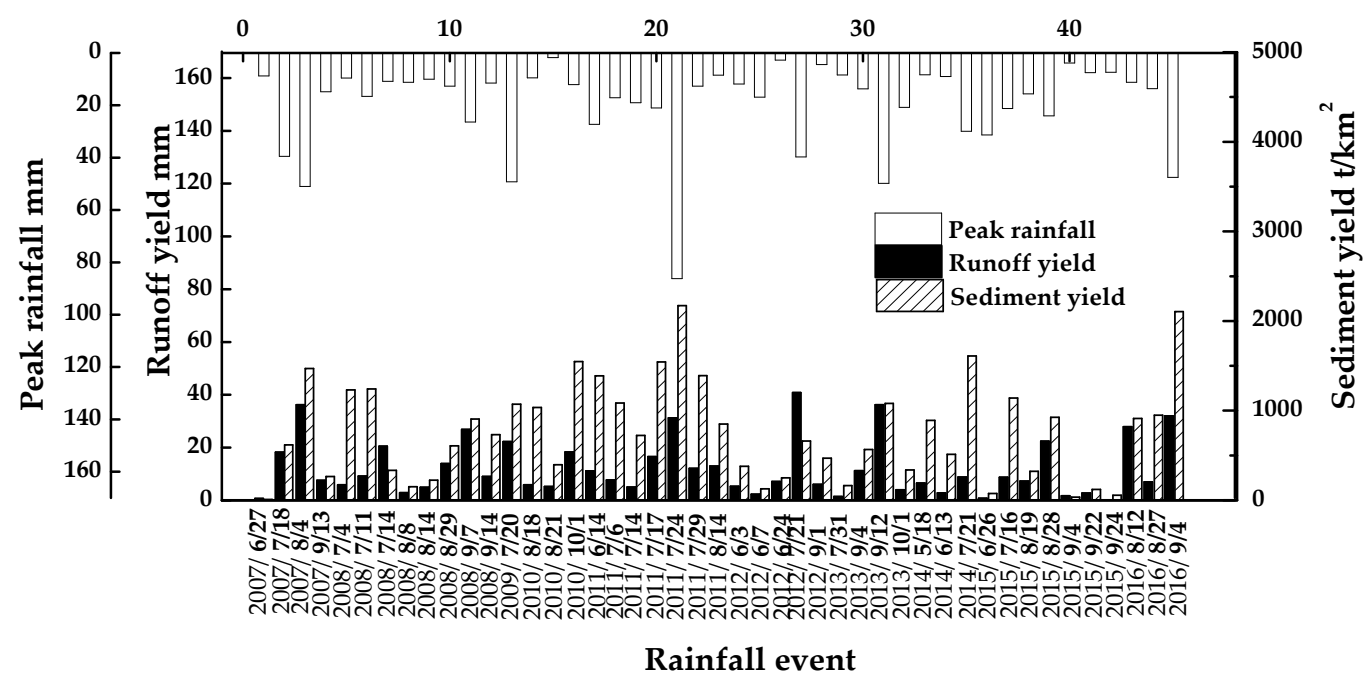

Figure 5. Variation of runoff and sediment with TPR.

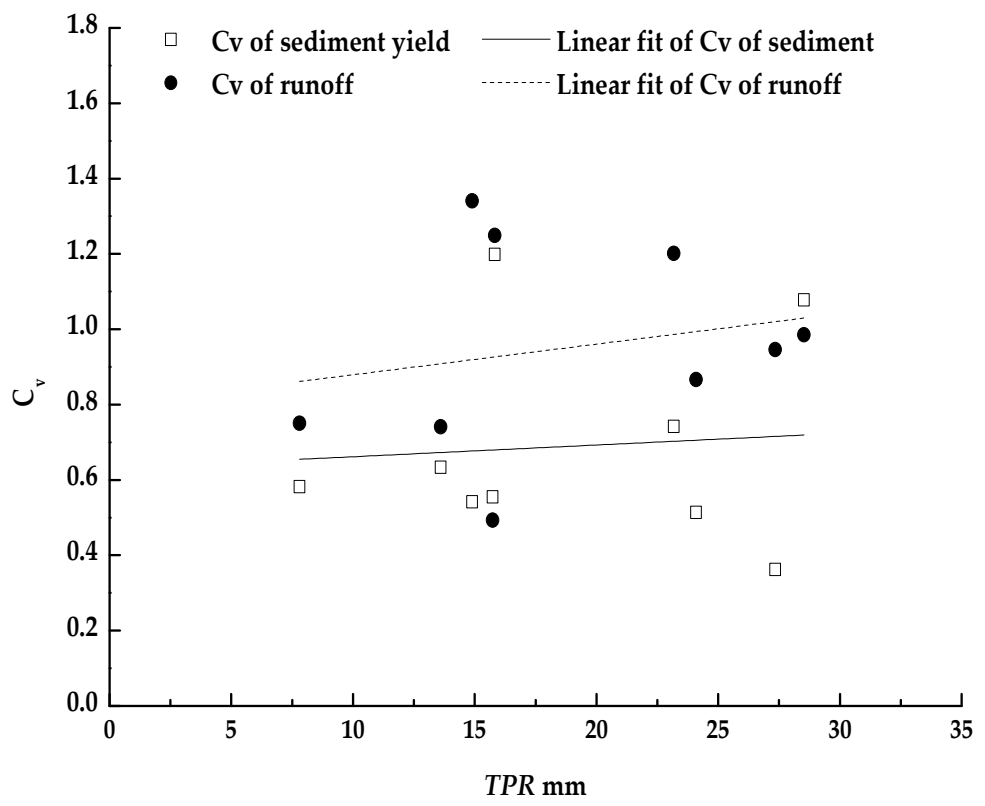

Figure 6. Change in the $C_{v}$ of the annual runoff and sediment yield with the total peak rainfall amount of one rainfall $(T P R)$.

\subsection{Explanatory Power of Statistical Rainfall Indexes on Changes in Runoff and Sediment Yield}

The correlation analysis between statistical rainfall indexes (rainfall amount, average rainfall intensity, rainfall duration, $I_{5}, I_{10}, I_{15}, I_{20}, I_{30}$, and $I_{60}$ ) and runoff and sediment yield were carried out. The results are shown in Table 4 . Except for the average rainfall intensity and rainfall duration, there were significant correlations between the characteristic indexes of rainfall and sediment yield. The correlation between $I_{60}$ and sediment yield was the largest $(0.60)$. It can be seen from the foregoing that the duration of a single peak was generally less than $40 \mathrm{~min}$ (Figure 2), and its characteristics could be expressed by any index of the maximum rainfall of 5-30 min. The correlation between $I_{60}$ and sediment yield was much greater than other statistical rainfall indexes, which indicated that the maximum rainfall of an intercept time of $60 \mathrm{~min}$ could accommodate more rainfall characteristics. However, it was not correct that the larger the interception time range was, the more the maximum rainfall in a given period is related to sediment yield because the correlation between rainfall amount and sediment yield was also low when the interception range was all time. It was probably related to the peak number and continuity in the rainfall process. $I_{60}$ might reflect the comprehensive characteristics 
of multi-peak rainfall and their continuity to a certain extent, that was to say, the more continuous rain peaks occurred within one hour and the larger the peak value, the greater the sediment yield produced. The analysis of multi-peak continuity in Section 3.2.1 proved that when the peak interval is within a certain period of time (about $90 \mathrm{~min}$ ), multi-peak continuity had a significant impact on sediment yield.

The trend of the relationship between runoff and maximum rainfall in a given period was consistent with sediment yield, except that the correlation between runoff and rainfall amount was also large. The statistical rainfall characteristic indexes with the strongest correlation with runoff were rainfall amount and $I_{60}$ (Table 4), and the correlation coefficients were 0.75 and 0.69 , respectively.

A comprehensive comparison between the indexes of rainfall peak morphology and statistical rainfall characteristic indexes showed that $T P R$ and $I_{60}$ were most closely related to runoff and sediment yield. Therefore, linear regression models were established with sediment yield $(S)$ and runoff $(R)$ as dependent variables, and TPR $(P)$ and $I_{60}$ as independent variables. The results are shown in Table 5 . Five rainfall events were randomly sampled for cross-checking, and the relative error, correlation coefficient, and Nash-Sutcliffe efficiency coefficient of predicted values with measured values were obtained. The remaining rainfalls were used for relationship fitting. TPR could explain $62 \%$ of the runoff variety and $36 \%$ of the sediment yield variety, which was greater than explanatory power of $I_{60}(51 \%, 37 \%)$. In general, TPR and $I_{60}$ had more explanatory power for runoff than sediment yield. The cross-examination results of measured and simulated values of runoff yield model showed that the mean relative error of the two runoff models proposed in the study were $22.4 \%$ and $12.1 \%$, the correlation coefficient was 0.91 and 0.94 , and the Nash-Sutcliffe efficiency coefficient was 0.72 and 0.93 , respectively. The models had good application precision. However, the mean relative error of the sediment yield model was larger, reaching more than $50 \%$, and the Nash-Sutcliffe efficiency coefficient was less than 0 , which indicated that its application precision was weak.

Table 5. Regression model of runoff and sediment yield.

\begin{tabular}{ccccccc}
\hline \multirow{2}{*}{ Plot Code } & \multirow{2}{*}{ Equations } & \multirow{2}{*}{$\boldsymbol{R}^{\mathbf{2}}$} & $\boldsymbol{P}$ & \multicolumn{3}{c}{ Cross-Examination } \\
\cline { 5 - 7 } & & & & $\boldsymbol{M R E} \mathbf{( \% )}$ & $\boldsymbol{R}$ & $\boldsymbol{E}_{\boldsymbol{n} \boldsymbol{s}}$ \\
\hline 1 & $R=-0.25+0.64 P$ & 0.62 & $<0.05$ & 22.4 & 0.91 & 0.72 \\
2 & $R=-7.25+0.99 I_{60}$ & 0.51 & $<0.05$ & 12.1 & 0.94 & 0.93 \\
3 & $S=376.68+20.02 P$ & 0.36 & $<0.05$ & 68.4 & 0.87 & -1.86 \\
4 & $S=34.91+36.93 I_{60}$ & 0.37 & $<0.05$ & 56.1 & 0.97 & -0.19 \\
\hline
\end{tabular}

Note: $R^{2}$ means coefficient of determination; $P$ means significance test probability.

\section{Discussion}

Previous studies on how rainfall affects runoff and sediment yield have mostly focused on statistical descriptions of rainfall (rainfall, average rainfall intensity, duration of rainfall, and maximum rainfall in a given period), and maximum rainfall in a given time, with less than $30 \mathrm{~min}$ being the most common $[19,20]$. In this study, the correlation between rainfall and runoff was strong, but the correlation between rainfall and sediment yield was weak, and the average rainfall intensity had no significant correlation with runoff and sediment yield. This showed that the average rainfall intensity could not reflect the natural rainfall with instantaneous variation in rainfall intensity in the study of soil erosion. $I_{30}$ could only reflect the characteristics of the highest rainfall peak, ignoring the situation of multiple peaks in the rainfall process. The results showed that there were significant differences in runoff and sediment yield between single-peak and multi-peak rainfalls. The continuity between rainfall peaks was rarely considered. In this paper, it was found that a distance of $90 \mathrm{~min}$ between the two rain peaks was a change point, and there were significant differences in soil loss caused by rainfall within and outside 90 min between the two peaks, which were concealed by correlation analysis. 
The analysis of this study based on natural rainfall showed that the peak position had a significant impact on runoff, that is, the runoff caused by middle-position rainfalls was significantly larger than that caused by front-position rainfalls, while the peak position had no significant impact on sediment yield. Previous studies using simulated rainfall showed that more sediment could be generated by rear-position rainfall $[18,21,22]$. They believed that as the rain continued, the soil water content gradually increased, which led to the decline of infiltration capacity and an increase in runoff, or continuous high-intensity rainfall might lead to a change in soil structure. Flanagan [11] believed that when the soil was dry before a rainfall, a rear-position rainfall was more conducive to runoff generation, while if the soil was wet before a rainfall, a front-position rainfall could cause more runoff and soil loss. It was not found that the peak position had a significant effect on sediment yield in this study, which might be due to the different soil conditions under simulated rainfall and natural rainfall. Under artificial simulated rainfall conditions, the soil was relatively loose, which was not conducive to the formation of crusts [22]. Under natural conditions, the rear-position rainfall was favorable for the formation of a soil crust, that is, a storm with a lower initial rainfall intensity offered more opportunity for surface seal development, which was more resistant to erosion by surface flow [23]. On the contrary, the soil surface of the front-position rainfall under natural conditions was not protected by a crust, which was beneficial for sediment yield. Therefore, although the front-position rainfall produced less runoff than the middle- and rear-position rainfall, the sediment yield of the front-position rainfall was comparable to that of the middle- and rear-position rainfall. Frauenfeld and Truman [12] also found that the effect of rainfall patterns on sediment yield varied with soil type and texture.

Peak value and peak width had important effects on runoff and sediment yield, which could be expressed by TPR. The larger the peak value and width, the larger the TPR, and the larger the runoff and sediment yield. The results showed that the explanatory power of $T P R$ for the runoff was $72 \%$, with a higher correlation coefficient and Nash-Suttclife efficiency coefficient, and a relative error less than $30 \%$, which indicated that the statistical model based on TPR had good application precision. The unexplained part might be due to: (1) This study based the rainfall events without anticipated rainfall within 2 days, which could not completely guarantee the consistency of soil water content before rain, and could not completely exclude the influence of soil water content. (2) The TPR could not accommodate the characteristics of rain peaks, such as peak position and continuity. (3) The nature of raindrops was not involved. (4) The interaction between rainfall and soil permeability.

The explanatory power of TPR on sediment yield was 36\% with a low Nash-Sutcliffe efficiency coefficient, and a relative error more than $50 \%$, which was similar to the research of Liu [24] on the application of the WEPP(water erosion prediction project) model to bare slope land in the black soil region of northeast China. This might be related to the type of soil and runoff process. Rainfall and runoff with different morphologies formed a complex response mechanism with soil particles, thus reducing the prediction accuracy of rainfall characteristic indicators on sediment yield. Further research is needed regarding how the interaction between rainfall and soil permeability affects runoff and how the interaction between rainfall, runoff and soil physical properties affects sediment yield.

\section{Conclusions}

(1) The order of influence of rainfall peak morphological indexes on runoff was peak width $>$ peak number $>$ peak value $>$ peak position, and the order of the influence on sediment was peak width $>$ peak value $>$ peak number $>$ peak position. Multi-peak continuity was not significantly correlated with runoff and sediment yield. 
(2) Runoff and sediment yield increased significantly when the number of rainfall peaks reached two or more. The average interval time of 90 min between peaks of a multi-peak rainfall acted as the critical point, and there was a significant difference between the sediment with a peak continuity $\leq 1 / 90 \mathrm{~min}^{-1}$ and $>1 / 90 \mathrm{~min}^{-1}$. With an increase in peak continuity, the sediment yield showed an increasing trend. In this study area, a rainfall peak with an average interval of less than $90 \mathrm{~min}$ (continuity $>1 / 90 \mathrm{~min}^{-1}$ ) was most common, accounting for $84 \%$.

(3) Analysis of variance showed peak position had no significant effect on soil erosion, but it had a significant effect on runoff. The runoff formed by middle-position rainfalls was significantly more than that of front-position rainfalls, which may be related to the formation of a soil crust.

(4) Peak number, peak value, and peak width had a correlation with runoff and sediment yield. With an increase in peak number, peak value and peak width, runoff and sediment yield also increased. As a comprehensive index, TPR could take into account all of the above factors and had the highest correlation with runoff and sediment yield.

(5) $I_{30}$ could only reflect the rainfall characteristics of the highest peak because the rainfall peak width was generally below $40 \mathrm{~min}$ in the study area. However, $I_{60}$ had a better explanatory power for runoff and sediment yield and could take more factors into account to a certain extent, such as multi-peaks and peak continuity.

(6) The regression equations established by TPR and $I_{60}$ on runoff had good application precision. The prediction error was within $30 \%$, and the correlation coefficient and the Nash-Sutcliffe efficiency coefficient were relatively high. Moreover, the interpretation of the TPR on the runoff was stronger than $I_{60}$. The precision of the regression equation established by TPR and $I_{60}$ on the sediment yield was poor.

Author Contributions: Conceptualization, J.X.; Formal analysis, J.X.; Funding acquisition, F.W.; Investigation, M.L.; Methodology, J.X. and J.Z.; Project administration, J.Z. and F.W.; Resources, J.Z. and F.W.; Software, J.X. and M.L.; Supervision, J.Z.; Visualization, M.L.; Writing—original draft, J.X.; Writing-review \& editing, J.X.

Funding: This research was funded by National Key Research and Development Program of China, grant number 2016YFC0501704.

Acknowledgments: We thank Shilei Wang and Xingle Yang (Engineer of soil and water conservation, Water and Soil Conservation Workstation in Miyun District, Beijing, China) for data collection and comments to earlier drafts of the manuscript.

Conflicts of Interest: The authors declare no conflict of interest. 


\section{Appendix A}

Table A1. The data set of Statistical Rainfall Indexes.

\begin{tabular}{|c|c|c|c|c|c|c|c|c|c|c|c|}
\hline Data & Rainfall Amount (mm) & Rainfall Duration (min) & Rainfall Intensity (mm/h) & $I_{5}(\mathrm{~mm} / \mathrm{h})$ & $I_{10}(\mathrm{~mm} / \mathrm{h})$ & $I_{15}(\mathrm{~mm} / \mathrm{h})$ & $I_{20}(\mathrm{~mm} / \mathrm{h})$ & $I_{30}(\mathrm{~mm} / \mathrm{h})$ & $I_{40}(\mathrm{~mm} / \mathrm{h})$ & $I_{50}(\mathrm{~mm} / \mathrm{h})$ & $I_{60}(\mathrm{~mm} / \mathrm{h})$ \\
\hline $2007 / 6 / 27$ & 26.6 & 560 & 2.85 & 43.20 & 36.60 & 35.20 & 29.10 & 23.00 & 18.60 & 16.44 & 15.90 \\
\hline 2007/7/18 & 46.1 & 150 & 18.44 & 72.00 & 66.00 & 56.80 & 54.60 & 45.00 & 39.00 & 31.92 & 26.60 \\
\hline $2007 / 8 / 4$ & 66.5 & 375 & 10.64 & 109.20 & 96.60 & 77.20 & 72.60 & 66.00 & 52.65 & 45.00 & 39.60 \\
\hline 2007/9/13 & 33.8 & 365 & 4.61 & 48.00 & 37.20 & 34.00 & 26.70 & 19.00 & 16.50 & 16.44 & 14.50 \\
\hline $2008 / 7 / 4$ & 17.5 & 430 & 2.44 & 84.00 & 57.60 & 44.80 & 34.05 & 23.00 & 17.25 & 13.80 & 11.50 \\
\hline 2008/7/11 & 18.8 & 45 & 25.07 & 56.40 & 55.20 & 54.40 & 49.80 & 35.60 & 28.05 & 22.56 & - \\
\hline 2008/7/14 & 51.9 & 1225 & 2.54 & 30.00 & 27.00 & 25.20 & 22.20 & 19.40 & 17.10 & 16.32 & 15.90 \\
\hline $2008 / 8 / 8$ & 16.8 & 750 & 1.34 & 42.00 & 36.00 & 30.00 & 24.00 & 16.80 & 15.00 & 14.16 & 12.50 \\
\hline 2008/8/14 & 13.3 & 155 & 5.15 & 60.00 & 60.00 & 41.60 & 31.80 & 21.80 & 16.65 & 13.56 & 11.80 \\
\hline 2008/8/29 & 21.8 & 1020 & 1.28 & 96.00 & 60.60 & 46.40 & 37.80 & 25.80 & 21.45 & 17.16 & 14.50 \\
\hline $2008 / 9 / 7$ & 34.5 & 240 & 9.00 & 108.00 & 100.20 & 85.60 & 66.30 & 48.80 & 42.45 & 35.28 & 30.40 \\
\hline 2008/9/14 & 16.6 & 95 & 10.48 & 106.80 & 58.80 & 49.60 & 39.90 & 28.40 & 21.45 & 17.28 & 14.60 \\
\hline 2009/7/20 & 54.8 & 220 & 15.66 & 127.20 & 117.60 & 92.00 & 77.40 & 54.00 & 40.80 & 32.76 & 27.70 \\
\hline 2010/8/18 & 19.7 & 134 & 8.82 & 43.20 & 43.20 & 38.00 & 31.50 & 23.8 & 20.3 & 16.7 & 16.2 \\
\hline $2010 / 8 / 21$ & 43.4 & 1155 & 2.25 & 21.60 & 16.80 & 13.60 & 12.00 & 12.2 & 10.1 & 8.8 & 7.9 \\
\hline 2010/10/1 & 38.5 & 618 & 3.74 & 30.00 & 30.00 & 29.60 & 28.80 & 27.0 & 24.2 & 22.1 & 20.6 \\
\hline $2011 / 6 / 14$ & 28.7 & 55 & 31.31 & 98.40 & 64.20 & 72.80 & 62.70 & 54.60 & 42.75 & 34.44 & 28.70 \\
\hline $2011 / 7 / 6$ & 30.1 & 320 & 5.64 & 60.00 & 43.80 & 36.20 & 36.90 & 30.20 & 26.40 & 21.84 & 18.70 \\
\hline 2011/7/14 & 22.3 & 140 & 9.56 & 67.20 & 55.20 & 44.40 & 43.80 & 39.40 & 31.50 & 25.20 & 21.90 \\
\hline $2011 / 7 / 17$ & 32.6 & 225 & 8.69 & 67.20 & 54.60 & 49.20 & 42.90 & 33.80 & 28.65 & 30.12 & 26.70 \\
\hline $2011 / 7 / 24$ & 105.2 & 470 & 13.43 & 126.00 & 99.00 & 86.40 & 75.30 & 56.60 & 45.90 & 42.48 & 42.90 \\
\hline $2011 / 7 / 29$ & 20.1 & 185 & 6.52 & 76.80 & 58.20 & 50.80 & 43.20 & 32.20 & 25.65 & 21.12 & 18.00 \\
\hline $2011 / 8 / 14$ & 25 & 555 & 2.70 & 48.00 & 39.00 & 35.60 & 27.30 & 19.10 & 14.40 & 11.76 & 9.90 \\
\hline $2012 / 6 / 3$ & 12.40 & 20 & 37.20 & 100.80 & 71.40 & 48.80 & 36.90 & 24.80 & 18.45 & 14.76 & 12.40 \\
\hline $2012 / 6 / 7$ & 18.30 & 75 & 14.64 & 48.00 & 45.60 & 41.60 & 37.20 & 33.80 & 26.25 & 21.24 & 17.90 \\
\hline $2012 / 6 / 24$ & 29.90 & 825 & 2.17 & 32.40 & 23.40 & 19.60 & 16.20 & 12.40 & 11.10 & 9.60 & 9.10 \\
\hline 2012/7/21 & 114.30 & 1040 & 6.59 & 69.60 & 51.00 & 47.20 & 43.50 & 34.00 & 31.80 & 28.32 & 24.60 \\
\hline $2012 / 9 / 1$ & 54.59 & 1095 & 2.99 & 27.60 & 26.40 & 18.80 & 14.40 & 11.60 & 11.40 & 11.04 & 10.50 \\
\hline $2013 / 7 / 31$ & 17.00 & 240 & 4.25 & 58.80 & 50.40 & 35.20 & 27.90 & 18.60 & 15.15 & 12.84 & 11.00 \\
\hline $2013 / 9 / 4$ & 62.50 & 625 & 6.00 & 42.00 & 34.20 & 34.80 & 33.60 & 30.40 & 25.95 & 21.72 & 18.50 \\
\hline 2013/9/12 & 52.60 & 1215 & 2.60 & 138.00 & 99.00 & 82.00 & 72.30 & 30.00 & 55.50 & 49.20 & 41.00 \\
\hline 2013/10/1 & 33.30 & 215 & 9.29 & 68.40 & 64.20 & 60.80 & 57.00 & 44.60 & 36.45 & 30.12 & 26.10 \\
\hline 2014/5/18 & 9.8 & 40 & 14.7 & 33.60 & 33.00 & 25.20 & 18.90 & 6.7 & 14.7 & 11.76 & 9.8 \\
\hline $2014 / 6 / 13$ & 11.7 & 55 & 12.76 & 66.00 & 54.00 & 38.80 & 31.20 & 22.2 & 16.95 & 13.92 & 11.7 \\
\hline $2014 / 7 / 21$ & 30 & 85 & 21.18 & 108.00 & 84.00 & 73.2 & 67.2 & 57.6 & 45.75 & 36.72 & 30.6 \\
\hline $2015 / 6 / 26$ & 32.4 & 110 & 17.67 & 176.40 & 173.40 & 125.20 & 93.90 & 62.6 & 47.3 & 37.9 & 31.7 \\
\hline $2015 / 7 / 16$ & 26.8 & 160 & 10.05 & 151.20 & 79.80 & 54.40 & 41.40 & 28.6 & 33.5 & 28.0 & 23.8 \\
\hline 2015/8/19 & 15.4 & 21 & 44.00 & 72.00 & 57.00 & 50.80 & 46.80 & 15.8 & 23.7 & 19.0 & 15.8 \\
\hline $2015 / 8 / 28$ & 28.7 & 110 & 15.65 & 146.40 & 103.20 & 83.60 & 72.00 & 54.0 & 41.1 & 33.5 & 28.0 \\
\hline $2015 / 9 / 4$ & 27.6 & 1060 & 1.56 & 24.00 & 21.00 & $\begin{array}{l}18.00 \\
18.00\end{array}$ & 15.00 & 10.0 & $\begin{array}{l}11.1 \\
11.7\end{array}$ & 10.9 & 9.8 \\
\hline 2015/9/22 & 12.6 & 130 & 5.82 & 48.00 & 45.00 & 35.60 & 30.90 & 24.2 & 18.3 & 14.6 & 12.3 \\
\hline 2015/9/24 & 11.0 & 80 & 8.25 & 60.00 & 44.40 & 32.80 & 25.50 & 19.0 & 14.4 & 11.6 & 10.3 \\
\hline 2016/8/12 & 36.2 & 500 & 4.3 & 51.60 & 40.80 & 36.40 & 33.30 & 28.8 & 24.6 & 22.7 & 20.4 \\
\hline 2016/8/27 & 15.1 & 35 & 25.9 & 108.00 & 81.60 & 57.20 & 43.65 & 30.0 & 22.5 & 18.0 & 15.0 \\
\hline $2016 / 9 / 4$ & 57.6 & 370 & 9.3 & 84.00 & 66.00 & 58.00 & 49.50 & 34.8 & 31.4 & 29.3 & 26.7 \\
\hline
\end{tabular}


Table A2. The data set of morphological characteristics of rainfall peak.

\begin{tabular}{|c|c|c|c|c|c|c|c|c|c|c|c|c|c|}
\hline Data & $\begin{array}{c}\text { Peak } \\
\text { Number }\end{array}$ & $\begin{array}{c}\text { Peak } \\
\text { Position }\end{array}$ & $\begin{array}{l}\text { Peak Position } \\
\text { Value }^{1}\end{array}$ & $\begin{array}{l}\text { Peak Width } \\
\text { (min) }\end{array}$ & $\begin{array}{l}\text { Highest Peak } \\
\text { Width (min) }\end{array}$ & $\begin{array}{l}\text { Peak Width of } \\
\text { One Rainfall } \\
\text { (min) }\end{array}$ & $\begin{array}{l}\text { Highest Peak } \\
\text { Value }(\mathrm{mm})\end{array}$ & $\begin{array}{c}\text { Interval Time } \\
\text { of Multi-Peak } \\
\text { ( (min) }\end{array}$ & $\begin{array}{c}\text { Total Interval } \\
\text { Time of } \\
\text { Multi-Peak (min) }\end{array}$ & $\begin{array}{c}\text { Peak } \\
\text { Continuity } \\
\left(\mathrm{min}^{-1}\right)\end{array}$ & $\begin{array}{l}\text { Peak Rainfall } \\
\text { Amount }(\mathrm{mm})\end{array}$ & $\begin{array}{c}\text { Highest Peak } \\
\text { Rainfall } \\
\text { Amount (mm) }\end{array}$ & $\begin{array}{c}\text { Total Peak } \\
\text { Rainfall } \\
\text { Amount }(\mathrm{mm})\end{array}$ \\
\hline 2007/6/27 & 1 & front & 15 & 15 & 15 & 15 & 0.72 & - & - & - & - & 8.80 & 8.80 \\
\hline $2007 / 7 / 18$ & 2 & rear & 45 & $15 / 35$ & 15 & 50 & 1.20 & 55 & 55.00 & 0.02 & $15 / 24.5$ & 15.00 & 39.50 \\
\hline $2007 / 8 / 4$ & 4 & rear & 15 & $5 / 10 / 15 / 35$ & 35 & 65 & $\begin{array}{l}1.20 \\
\end{array}$ & $30 / 150 / 75$ & 85 & 0.01 & $2 / 4.2 / 9.9 / 34.9$ & 34.90 & 51.00 \\
\hline $2008 / 7 / 4$ & 1 & front & 65 & 10 & 10 & 10 & 1.40 & - & - & - & - & 7.00 & 9.60 \\
\hline $2008 / 7 / 11$ & 1 & front & 5 & 20 & 20 & 20 & 0.94 & - & - & - & - & 16.60 & 16.60 \\
\hline 2008/7/14 & 3 & middle & 345 & $5 / 15 / 5$ & 15 & 25 & 0.50 & $380 / 45$ & 212.5 & 0.00 & $2.5 / 6.3 / 2$ & 6.30 & 10.80 \\
\hline $2008 / 8 / 8$ & 2 & front & 5 & $10 / 5$ & 10 & 15 & 0.70 & 230 & 230 & 0.00 & $5.1 / 6.1$ & 5.10 & 11.20 \\
\hline 2008/8/14 & 1 & front & 0 & 10 & 10 & 10 & 1.00 & - & - & - & - & 10.00 & 10.00 \\
\hline $2008 / 8 / 29$ & 2 & rear & 125 & $5 / 10$ & 10 & 15 & 1.60 & 850 & 850 & 0.00 & $2.6 / 10.1$ & 10.10 & 12.70 \\
\hline $2008 / 9 / 14$ & 1 & front & 5 & 10 & 10 & 10 & 1.78 & - & - & - & & 11.50 & 11.50 \\
\hline $2009 / 7 / 20$ & 2 & middle & 10 & $30 / 20$ & 20 & 50 & 2.12 & 60 & 60 & 0.02 & $23.4 / 25.8$ & 25.80 & 49.20 \\
\hline $2010 / 8 / 18$ & 1 & middle & 80 & 15 & 10 & 20 & 0.72 & - & - & 0.02 & 9.50 & 9.50 & 9.50 \\
\hline $2010 / 8 / 21$ & 1 & middle & 555 & 5 & 5 & 5 & 0.36 & - & - & - & - & 1.80 & 1.80 \\
\hline 2010/10/1 & 1 & middle & 200 & 35 & 35 & 35 & 0.50 & - & - & - & - & 12.10 & 12.10 \\
\hline $2011 / 6 / 14$ & 1 & front & 15 & 30 & 30 & 30 & 1.64 & - & 0 & - & - & 27.30 & 27.30 \\
\hline $2011 / 7 / 6$ & 4 & rear & 0 & $10 / 10 / 5 / 5$ & 10 & 30 & 1.00 & $215 / 5 / 5$ & 75 & 0.01 & $6.6 / 7.3 / 3.3 / 2.5$ & 7.30 & 17.10 \\
\hline $2011 / 7 / 14$ & 1 & front & 5 & 25 & 25 & 25 & 1.12 & 25 & 25 & 0.04 & 19.00 & 19.00 & 19.00 \\
\hline $2011 / 7 / 17$ & 2 & front & 5 & $25 / 10$ & 25 & 35 & 1.12 & 40 & 40 & 0.03 & $16.1 / 6.7$ & 16.10 & 21.00 \\
\hline $2011 / 7 / 24$ & 5 & middle & 265 & $35 / 25 / 5 / 5 / 50$ & 25 & 120 & 2.10 & $15 / 10 / 10 / 5$ & 10 & 0.10 & 10.9/11.2/27.2/2/32.7 & $\begin{array}{ll}7 & 11.20\end{array}$ & 86.20 \\
\hline $2011 / 7 / 29$ & 1 & middle & 70 & 15 & 15 & 15 & 1.28 & $10 / 10 / 10 / 3$ & - & 0.10 & 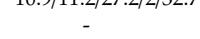 & 12.70 & 12.70 \\
\hline $2011 / 8 / 14$ & 2 & middle & 220 & $15 / 5$ & 15 & 20 & 0.80 & 70 & 70 & 0.01 & $8.5 / 3.3$ & 8.50 & 8.50 \\
\hline $2012 / 6 / 3$ & 1 & rear & 150 & 10 & 10 & 10 & 1.68 & - & - & - & - & 11.90 & 11.90 \\
\hline $2012 / 7 / 21$ & 5 & middle & 160 & 10/10/5/10/10 & 10 & 45 & 1.16 & $20 / 20 / 100 / 0$ & 35 & 0.03 & $5.4 / 3.8 / 11.8 / 14.5 / 4.2$ & 14.50 & 39.70 \\
\hline $2012 / 9 / 1$ & 1 & rear & $\begin{array}{l}100 \\
670\end{array}$ & 10 & 10 & $\begin{array}{l}45 \\
10\end{array}$ & 0.46 & $20 / \angle 0 / 100 / 0$ & $\begin{array}{l}30 \\
0.00\end{array}$ & 0.00 & - 5.4/0.0/11.0/14.0/4.2 & $\begin{array}{l}14.50 \\
4.40\end{array}$ & $\begin{array}{l}39.10 \\
4.40\end{array}$ \\
\hline $2013 / 7 / 31$ & 1 & front & 20 & 10 & 10 & 10 & 0.98 & - & 0.00 & - & - & 8.40 & 8.40 \\
\hline $2013 / 9 / 4$ & 4 & front & 35 & $5 / 20 / 5 / 5$ & 5 & 35 & 0.70 & $5 / 60 / 5$ & 23.33333 & 0.04 & $2.5 / 11.2 / 3.5 / 2$ & 3.50 & $\begin{array}{l}0.40 \\
13.70\end{array}$ \\
\hline 2013/9/12 & 3 & rear & 25 & $15 / 20 / 20$ & 20 & 55 & 2.30 & $60 / 25$ & 42.5 & 0.02 & $9.7 / 24.1 / 16$ & 24.10 & 49.80 \\
\hline 2013/10/1 & 1 & middle & 60 & 25 & 25 & 25 & 1.14 & - & - & & & 20.80 & 20.80 \\
\hline $2014 / 5 / 18$ & 2 & front & 5 & $5 / 10$ & 10 & 15 & 0.56 & 20 & 20 & 0.05 & $2.8 / 5.5$ & 5.50 & 8.30 \\
\hline $2014 / 6 / 13$ & 1 & front & 0 & 10 & 10 & 10 & 1.10 & - & - & - & - & 9.00 & 9.00 \\
\hline $2014 / 7 / 21$ & 1 & front & 0 & 30 & 30 & 30 & 1.80 & - & - & - & $8.5 / 21.5$ & 29.90 & 29.90 \\
\hline $2015 / 6 / 26$ & 1 & front & 0 & 15 & 15 & 15 & 2.94 & - & - & - & & 31.30 & 31.30 \\
\hline $2015 / 7 / 16$ & 2 & front & 5 & $10 / 5$ & 5 & 15 & 2.52 & 30 & 30 & 0.03 & $8.6 / 12.6$ & 12.60 & 21.20 \\
\hline $\begin{array}{l}2015 / 8 / 19 \\
2\end{array}$ & 1 & front & 5 & 20 & 20 & 20 & 1.20 & - & - & 0.03 & $0.0 / 12.0$ & $\begin{array}{l}12.00 \\
15.60\end{array}$ & $\begin{array}{l}15.60 \\
15.60\end{array}$ \\
\hline $2015 / 8 / 28$ & 1 & front & 20 & 20 & 20 & 20 & 2.44 & - & - & - & - & 24.00 & 24.00 \\
\hline $2015 / 9 / 4$ & 1 & front & 335 & 5 & 5 & 5 & 0.40 & - & - & - & - & 3.80 & 3.80 \\
\hline $2015 / 9 / 22$ & 1 & front & 5 & 10 & 10 & 10 & 0.80 & - & - & - & - & 7.50 & 7.50 \\
\hline $2015 / 9 / 24$ & 1 & front & 0 & 10 & 10 & 10 & 1.00 & - & - & - & - & 7.40 & 7.40 \\
\hline $2016 / 8 / 12$ & 2 & middle & 50 & $5 / 20$ & 20 & 25 & 0.86 & - & - & - & - & 11.20 & 11.20 \\
\hline $2016 / 8 / 27$ & 1 & front & 0 & 10 & 10 & 10 & 1.80 & - & - & - & - & 13.60 & 13.60 \\
\hline $2016 / 9 / 4$ & 3 & middle & 80 & $20 / 15 / 20$ & 15 & 55 & 1.40 & $110 / 40$ & 75 & 0.01 & $16.5 / 14 / 8.5$ & 14.00 & 47.50 \\
\hline
\end{tabular}


Table A3. The data set of runoff plots.

\begin{tabular}{|c|c|c|c|c|}
\hline Date & Sediment (Plot 3) & Sediment (Plot 4) & Runoff (Plot 3) & Runoff (Plot 4) \\
\hline $2007 / 6 / 27$ & 10.74 & 7.59 & 0.93 & 0.48 \\
\hline 2007/7/18 & 641 & 596.55 & 25.04 & 11.54 \\
\hline $2007 / 8 / 4$ & 1509.81 & 1429.82 & 44.77 & 27.67 \\
\hline $2007 / 9 / 13$ & 286.31 & 245.33 & 7.9 & 7.34 \\
\hline $2008 / 7 / 4$ & 1149.43 & 1314.84 & 5.04 & 6.76 \\
\hline 2008/7/11 & 1015.74 & 1469.81 & 9.09 & 9.27 \\
\hline $2008 / 7 / 14$ & 324.77 & 340.86 & 25.03 & 16.03 \\
\hline $2008 / 8 / 8$ & 102.09 & 198.3 & 2.79 & 3.02 \\
\hline $2008 / 8 / 14$ & 182.04 & 264.26 & 5.41 & 4.5 \\
\hline $2008 / 8 / 29$ & 539.84 & 672.23 & 13.5 & 14.4 \\
\hline $2008 / 9 / 7$ & 768.55 & 1045.17 & 29.62 & 24.22 \\
\hline $2008 / 9 / 14$ & 613.31 & 850.36 & 9 & 9.18 \\
\hline $2009 / 7 / 20$ & 1188.1 & 954.4 & 35.8 & 8.8 \\
\hline 2010/8/18 & 1192.31 & 879.39 & 6.39 & 5.38 \\
\hline $2010 / 8 / 21$ & 460.21 & 329.86 & 6.39 & 4.13 \\
\hline $2010 / 10 / 1$ & 1716.51 & 1379.21 & 19.69 & 16.99 \\
\hline $2011 / 6 / 14$ & 1542.1 & 1234.93 & 13.45 & 8.95 \\
\hline $2011 / 7 / 6$ & 1118.74 & 1051.87 & 8.3 & 7.17 \\
\hline $2011 / 7 / 14$ & 739.71 & 707.67 & 5.93 & 4.19 \\
\hline 2011/7/17 & 1527.13 & 1559.76 & 18.81 & 14.31 \\
\hline $2011 / 7 / 24$ & 2440.44 & 1904.11 & 38.7 & 23.86 \\
\hline $2011 / 7 / 29$ & 1353.62 & 1425.82 & 15.3 & 9 \\
\hline $2011 / 8 / 14$ & 755.24 & 944.5 & 17.06 & 8.96 \\
\hline $2012 / 6 / 3$ & 302.29 & 456.23 & 6.68 & 3.94 \\
\hline $2012 / 6 / 7$ & 175.01 & 80.45 & 2.65 & 2.09 \\
\hline $2012 / 6 / 24$ & 314.15 & 183.73 & 8.73 & 5.57 \\
\hline $2012 / 7 / 21$ & 578.96 & 740.84 & 28.27 & 53.47 \\
\hline $2012 / 9 / 1$ & 547.84 & 389.61 & 7.39 & 4.79 \\
\hline $2013 / 7 / 31$ & 222.19 & 104.92 & 1.77 & 1.1 \\
\hline $2013 / 9 / 4$ & 706.23 & 424.52 & 14.18 & 8.33 \\
\hline 2013/9/12 & 1132.77 & 1028.77 & 37.62 & 34.92 \\
\hline $2013 / 10 / 1$ & 384.58 & 289.81 & 4.52 & 3.5 \\
\hline $2014 / 5 / 18$ & 689.31 & 1092.13 & 5.48 & 7.74 \\
\hline $2014 / 6 / 13$ & 630.61 & 394.5 & 2.77 & 2.99 \\
\hline $2014 / 7 / 21$ & 1738.23 & 1480.98 & 8.89 & 8.78 \\
\hline $2015 / 6 / 26$ & 89.56 & 62.94 & 0.75 & 0.87 \\
\hline $2015 / 7 / 16$ & 1330.75 & 949.2 & 8.91 & 8.57 \\
\hline $2015 / 8 / 19$ & 412 & 234.91 & 8.06 & 6.48 \\
\hline $2015 / 8 / 28$ & 688.07 & 1164.96 & 25.1 & 19.7 \\
\hline $2015 / 9 / 4$ & 51.51 & 18.67 & 2.35 & 1.11 \\
\hline $2015 / 9 / 22$ & 150.83 & 90.78 & 2.88 & 2.65 \\
\hline $2015 / 9 / 24$ & 82.48 & 31.16 & 0.19 & 0.1 \\
\hline 2016/8/12 & 1161.85 & 663.57 & 28.8 & 27 \\
\hline $2016 / 8 / 27$ & 1245.27 & 651.07 & 6.78 & 7.23 \\
\hline $2016 / 9 / 4$ & 2534.04 & 1677.23 & 31.54 & 32.44 \\
\hline
\end{tabular}

\section{References}

1. Fraser, A.I.; Harrod, T.R.; Haygarth, P.M. The effect of rainfall intensity on soil erosion and particulate phosphorus transfer from arable soils. Water Sci. Technol. 1999, 39, 41-45. [CrossRef]

2. Greer, J.D. Effect of excessive rate rainstorms on erosion. J. Soil Water Conserv. 1971, 24, 196-197.

3. Chaplot, V.; Le Bissonnais, Y. Runoff features for interrill erosion at different rainfall intensities, slope lengths and gradients in an agricultural loessial hillslope. Soil Sci. Soc. Am. J. 2003, 67, 844-851. [CrossRef]

4. Wang, W.Z.; Jiao, J.Y.; He, X.P. Study on rainfall erosivity in china. J. Soil Water Conserv. 1995, 9, 6-18.

5. Zhang, X.K.; Xu, J.H.; Lu, X.Q.; Deng, Y.J.; Gao, D.W. A study on the soil loss Equation in Heilongjiang Province. Bull. Soil Water Conserv. 1992, 12, 2-17. 
6. Wischmeier, W.H.; Smith, D.D. Predicting Rainfall Erosion Losses from Cropland East of the Rocky Mountains, 1st ed.; United States Department of Agriculture: Washington, DC, USA, 1965; p. 282.

7. Bagarello, V.; D’Asaro, F. Estimating single storm erosion index. Trans. Am. Soc. Agric. Eng. 1994, 37, 785-791. [CrossRef]

8. Truman, C.C.; Bradford, J.M. Relationships between rainfall intensity and the interill soil loss-slope steepness ratio as affected by antecedent water content. Soil Sci. 1993, 156, 405-413. [CrossRef]

9. Assouline, S.; Ben-Hur, M. Effects of rainfall intensity and slope gradient on the dynamics of interrill erosion during soil surface sealing. Catena 2006, 66, 211-220. [CrossRef]

10. Arnáez, J.; Lasanta, T.; Ruiz-Flaño, P.; Ortigosa, L. Factors affecting runoff and erosion under simulated rainfall in Mediterranean vineyards. Soil Tillage Res. 2007, 93, 324-334. [CrossRef]

11. Flanagan, D.C.; Foster, G.R.; Moldenhauer, W.C. Storm pattern effect on infiltration, runoff, and erosion. Trans. ASABE 1988, 31, 414-420. [CrossRef]

12. Frauenfeld, B.; Truman, C. Variable rainfall intensity effects on runoff and interrill erosion from two coastal plain ultisols in Georgia. Soil Sci. 2004, 169, 143-154. [CrossRef]

13. Parsons, A.J.; Stone, P.M. Effects of intra-storm variations in rainfall intensity on interrill runoff and erosion. Catena 2006, 67, 68-78. [CrossRef]

14. Dunkerley, D. Effects of rainfall intensity fluctuations on infiltration and runoff: Rainfall simulation on dryland soils, Fowlers Gap, Australia. Hydrol. Process. 2012, 26, 2211-2224. [CrossRef]

15. Qin, W.; Zuo, C.Q.; Yan, Q.H.; Wang, Z.Y.; Du, P.F.; Yan, N. Regularity of individual rainfall soil erosion in bare slope land of red soil. Trans. Chin. Soc. Agric. Eng. 2015, 31, 124-132.

16. Hudson, N.W. Soil Conservation, 1st ed.; B.T. Batsford Ltd.: London, UK, 1976.

17. Huff, F.A. Time distribution of rainfall in heavy storms. Water Resour. Res. 1967, 3, 1007-1019. [CrossRef]

18. Wang, W.T.; Yin, S.Q.; Xie, Y.; Liu, B.Y.; Liu, Y.N. Effects of four storm patterns on soil loss from five soils under natural rainfall. Catena 2016, 141, 56-65. [CrossRef]

19. Wischmeier, W.C.; Smith, D.D. Rainfall energy and its relationship to soil loss. Trans. Am. Geophys. Union 1958, 39, 285-291. [CrossRef]

20. Kinnell, P.I.A. Runoff ratio as a factor in the empirical modelling of soil erosion by individual rainstorms. Aust. J. Soil Res. 1997, 35, 1-13. [CrossRef]

21. An, J.; Zheng, F.L.; Han, Y. Effects of rainstorm patterns on runoff and sediment yield processes. Soil Sci. 2014, 179, 293-303. [CrossRef]

22. De Lima, J.L.M.P.; Souza, C.S.; Singh, V.P. Granulometric characterization of sediments transported by surface runoff generated by moving storms. Nonlinear Proc. Geophys. 2008, 15, 999-1011. [CrossRef]

23. Romkens, M.J.M.; Helming, K.; Prasad, S.N. Soil erosion under different rainfall intensities, surface roughness, and soil water regimes. Catena 2001, 46, 103-123. [CrossRef]

24. Liu, Y.L.; Zheng, F.L.; Wang, B.; Wang, Y.X.; Xie, Y.J.; Fan, H. Assessment of WEPP model applicability in black soil zone of northeast China: A case study of slope gradient and soil and water conservation measures. Bull. Soil Water Conserv. 2010, 30, 139-145.

(C) 2019 by the authors. Licensee MDPI, Basel, Switzerland. This article is an open access article distributed under the terms and conditions of the Creative Commons Attribution (CC BY) license (http://creativecommons.org/licenses/by/4.0/). 